\title{
DEVELOPMENT AND SOYBEAN LEAF CONSUMPTION BY Urbanus proteus proteus (L.)
}

\author{
Dori Edson Nava ${ }^{1,2}$; José Roberto Postali Parra ${ }^{1 *}$ \\ ${ }_{2}^{1}$ Depto. de Entomologia, Fitopatologia e Zoologia Agrícola - USP/ESALQ, C.P. 9 - CEP: 13418-900 - Piracicaba, SP. \\ ${ }^{2} \mathrm{CNPq}$ Fellow. \\ *Autor correspondente <jrpparra@esalq.usp.br>
}

\begin{abstract}
Urbanus proteus proteus (L.) is a defoliating pest of legumes, causing damage mainly on soybean (Glycine max (L.) Merr.) and bean (Phaseolus vulgaris L.), and, being a minor pest, little is known about its bioecology. The objective of this paper was to study the larval and pupal development of the insect and the foliar consumption during its instars. Durations of $16.7 ; 1.1 ; 11.4$ and 29.2 days were determined for the caterpillar, prepupal, and pupal stages, and the period from caterpillar-adult, respectively, with a total viability of $84.8 \%$. The larval stage had five instars and the consumption of leaf area was $214.3 \mathrm{~cm}^{2}$, with the consumption of the two last instars representing $96.9 \%$ of the total. Based on this value, the control level of the pest was estimated as 17 large caterpillars per sampling.

Key words: Hesperiidae, leaf consumption, soybean pests, control level, bean leaf roller

\section{DESENVOLVIMENTO E CONSUMO DE FOLHAS DE SOJA POR Urbanus proteus proteus (L.)}

\begin{abstract}
RESUMO: Urbanus proteus proteus (L.) é uma praga desfolhadora de leguminosas causando danos, principalmente em soja (Glycine max (L.) Merr.), e feijoeiro (Phaseolus vulgaris L.), e, por ser praga secundária, pouco se sabe a respeito de sua bioecologia. O presente trabalho teve por objetivo estudar 0 desenvolvimento larval e pupal do inseto e o consumo da área foliar nos diferentes ínstares. Determinaramse durações de 16,$7 ; 1,1 ; 11,4$ e 29,2 dias, para as fases de lagarta, pré-pupa, pupa e período lagartaadulto, respectivamente, com viabilidade total de $84,8 \%$. A fase larval apresentou cinco ínstares e o consumo foi de $214,3 \mathrm{~cm}^{2}$ de área foliar, sendo que, o consumo dos dois últimos ínstares representou $96,9 \%$ do total. Baseando-se neste valor, estimou-se o nível de controle da praga, como sendo de 17 lagartas grandes por amostragem.

Palavras-chave: Hesperiidae, consumo foliar, pragas de soja, nível de controle, enrolador de folhas
\end{abstract}

\section{INTRODUCTION}

Urbanus proteus (L.) is a defoliating pest of several legumes, such as cowpea [Vigna unguiculata (L.) Walp.], pea (Pisum sativum L.), faba bean (Vicia faba L.), common bean and soybean, and it occurs in the Brazilian states of Amazonas, Bahia, Ceará, Minas Gerais, Pará, Pernambuco, Rio de Janeiro, Rio Grande do Sul and São Paulo (Costa Lima, 1945). The caterpillars, known as "cabeça-de-fósforo" (Gallo et al., 1988) or bean leaf rollers, can be easily identified by their prominent head and dark coloration and because they have a habit of folding up the leaf to protect themselves against natural enemies (Greene, 1971). Besides Brazil, this species is reported to occur in Colombia, Mexico, the U.S.A. and Canada, and some aspects of its biology were studied in laboratory by Van Dam \& Wilde (1977), for the temperature range of 13 to $23^{\circ} \mathrm{C}$.

The soybean plant has been reported as one of the main hosts for this pest (Gallo et al., 1988; Carvalho \& Silva, 2000); even though little is known about its bioecology, since it is a minor pest, the damage being considerable only when its population in the field is high. Studies by Greene (1971) demonstrated that one $U$. proteus caterpillar can destroy about $190 \mathrm{~cm}^{2}$ of soybean foliage, which is a much larger area than that destroyed by other caterpillars that attack this legume, such as Anticarsia gemmatalis Hüb., which consumes about 90 $\mathrm{cm}^{2}$, or the loopers Pseudoplusia includens Walker and Rachiplusia nu (Guen.), which destroy approximately 120 $\mathrm{cm}^{2}$ of leaf area (Gallo et al., 1988; Pereyra, 1998).

The objective of this research was to study the larval and pupal development of the insect and the consumption of leaf area during its different instars, feeding on the soybean cultivar 'FT 109'.

\section{MATERIAL AND METHODS}

The studies were carried out under controlled conditions of temperature $\left(25 \pm 2^{\circ} \mathrm{C}\right)$, relative humidity (70 $\pm 10 \%)$ and photophase (14 hours); the caterpillars utilized in the trial came from eggs collected on soybean plants of a field, in Piracicaba, SP, Brazil, and identified as subspecies Urbanus proteus proteus (L.).

The larval development was studied by separating 30 recently-hatched caterpillars on Petri dishes, which were fed 'FT-109' soybean leaves, kept turgid with moistened filter paper placed at the bottom 
of the dishes. The food was changed daily and the head capsule width was also measured daily to determine the number of instars, with an ocular micrometer Wild model MM 5235 attached to a stereoscopic microscope. Measurements were taken until the prepupal stage, i.e., when the caterpillars stopped feeding, and the duration and viability of the caterpillar and prepupal stages were recorded. Pupae were transferred to plastic cups containing moistened vermiculite, and the duration and viability of the different stages were recorded.

During the larval development the consumption of foliage by $U$. p. proteus in the different instars was determined, by offering the caterpillars soybean leaf circles of known area, obtained using a cork punch. The food was changed daily, and the remaining area was recorded, by means of a CID foliar area measuring device, model Cl - 203 (CID Inc., USA). Consumption was determined by the difference between the initial and final areas.

In order to determine the number of instars the multimodal frequency curve of head capsule measurements was utilized, and hypotheses tested on the linearized model of Dyar's law were formulated, by using the MOBAE (Modelos Bioestatísticos para a Entomologia) software developed by Haddad et al., (1995). Consumption data were submitted to analysis of variance and means were compared by Tukey test at $5 \%$.

\section{RESULTS AND DISCUSSION}

Urbanus proteus proteus (L.) had five larval instars (Table 1) (Figure 1), coinciding with the figures reported by Van Dam \& Wilde (1977). The head capsule width growth followed Dyar's law, with a growth rate value (K) of 1.59. In relation to instar duration, the fourth and fifth instars were longer, relative to the other (Table 1), totaling, for the caterpillar stage, an overall duration of 16.8 days (Table 1 ). Durations of 1.1 and 11.4 days were determined for the prepupal and pupal stages, respectively, with a total viability of $84.9 \%$ (Table 2). Even though similar results were found by Van Dam \& Wilde (1977) for these development stages, they reported a longer duration for the later instars, leading to a longer duration for the caterpillar stage also, which could be related to the utilization of another cultivar as food or because they reared in temperatures ranging from 13 to $23^{\circ} \mathrm{C}$. In spite of the fact that we only studied the caterpillar-adult period, with a duration of 29.2 days (Table 2 ), the larval viability was high (mortality occurred only during the first instar), with no pupal mortality. Therefore, even though the egg stage was not studied, there are apparently no problems in rearing this insect in the laboratory, except for obtaining eggs, which is an aspect that was not investigated in this study, and which could be a problem, in many instances, with other hesperids (Van Dam \& Wilde, 1977).
The foliar consumption of soybean was higher during the fifth instar (87\% of the total) (Figure 2), being different from the other instars (Table 1). The fourth and fifth-instar caterpillars were responsible for $96.9 \%$ of the consumption, in agreement with results obtained by Higley (1992), which mentioned that most soybean defoliator consumption $90 \%$ during the last two instars, an ordinary characteristic of lepidopterans in general (Waldbauer, 1968). The total consumption, $214.3 \mathrm{~cm}^{2}$, was higher than that reported by Greene (1971), that is, $190 \mathrm{~cm}^{2}$ of leaf area.

The soybean plant can withstand a high degree of defoliation, with great capacity of recovery along its development. Until blooming it can withstand up to $30 \%$ defoliation, and after that it can resist around 15\% (Turnipseed, 1972). Considering that for Anticarsia gemmatalis Hüb. the control level is 40 large caterpillars per sampling before and after blooming, and taking into account the consumption of $U$. p. proteus obtained in the present research $\left(214 \mathrm{~cm}^{2}\right)$, the estimated control level for this pest is around 17 caterpillars sampled per beat sheet. Since the experiment was carried out with cultivar FT-109, it is possible that this value might be subjected to slight changes depending on the cultivar, regional climatic conditions, phenological stage of the plant, etc. However, the estimated level could help evaluate the control level for this pest, because the majority of the work on this subject has been done with only one cultivar.

Table 1 - Number of instars, mean head capsule width, instar duration, and leaf consumption of 'FT-109' soybean by Urbanus proteus proteus. Temperature $25 \pm 1^{\circ} \mathrm{C}$, $\mathrm{RH} 70 \pm 10 \%$ and 14-hour photophase.

\begin{tabular}{lccc}
\hline Instars & $\begin{array}{c}\text { Mean head } \\
\text { capsule width }\end{array}$ & Duration & \multicolumn{1}{c}{ Consumption* } \\
\hline & $----\mathrm{mm}----$ & --- day --- & $---\mathrm{cm}^{2}----$ \\
1 & $0.68 \pm 0.0041$ & $1.9 \pm 0.06$ & $0.27 \pm 0.02 \mathrm{c}$ \\
2 & $1.11 \pm 0.0029$ & $2.8 \pm 0.07$ & $1.30 \pm 0.07 \mathrm{c}$ \\
3 & $1.89 \pm 0.0036$ & $2.7 \pm 0.08$ & $5.04 \pm 0.18 \mathrm{c}$ \\
4 & $2.98 \pm 0.0030$ & $3.8 \pm 0.07$ & $21.53 \pm 0.61 \mathrm{~b}$ \\
5 & $4.49 \pm 0.0051$ & $5.6 \pm 0.09$ & $186.14 \pm 2.76 \mathrm{a}$ \\
\hline Total & - & 16.8 & 214.3 \\
\hline
\end{tabular}

*Means followed by a common letter are not different at $5 \%$ by Tukey test.

Table 2 - Duration and viability of the caterpillar, prepupal and pupal stages, and caterpillar-adult period of Urbanus proteus proteus. Temperature $25 \pm 1^{\circ} \mathrm{C}$, $\mathrm{RH} 70 \pm 10 \%$ and 14 -hour photophase. $(n=$ number of individuals).

\begin{tabular}{lccc}
\hline Stage/Period & $\mathrm{n}$ & Duration & Viability \\
\hline & & ---- day ---- & $----\%$---- \\
Caterpillar & 27 & $16.7 \pm 0.35$ & 87.9 \\
Prepupa & 26 & $1.1 \pm 0.16$ & 96.6 \\
Pupa & 26 & $11.4 \pm 0.27$ & 100 \\
Caterpillar-Adult & & 29.2 & 84.9 \\
\hline
\end{tabular}




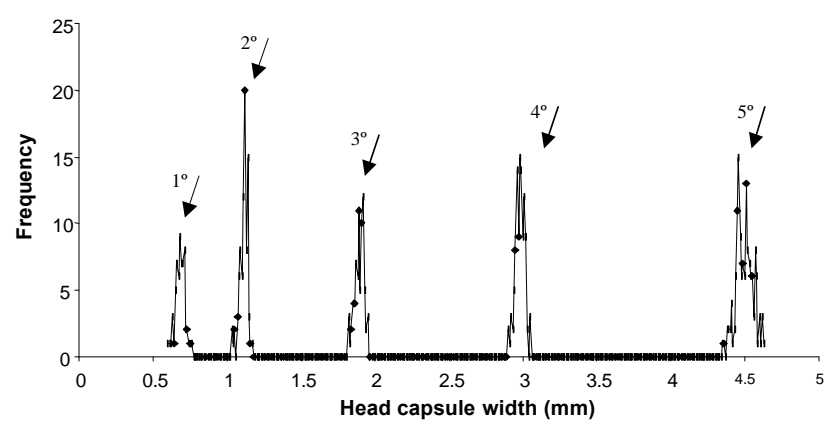

Figure 1 - Frequency distribution of head capsule measurements in Urbanus proteus proteus caterpillars. Arrows indicate the number of instars.

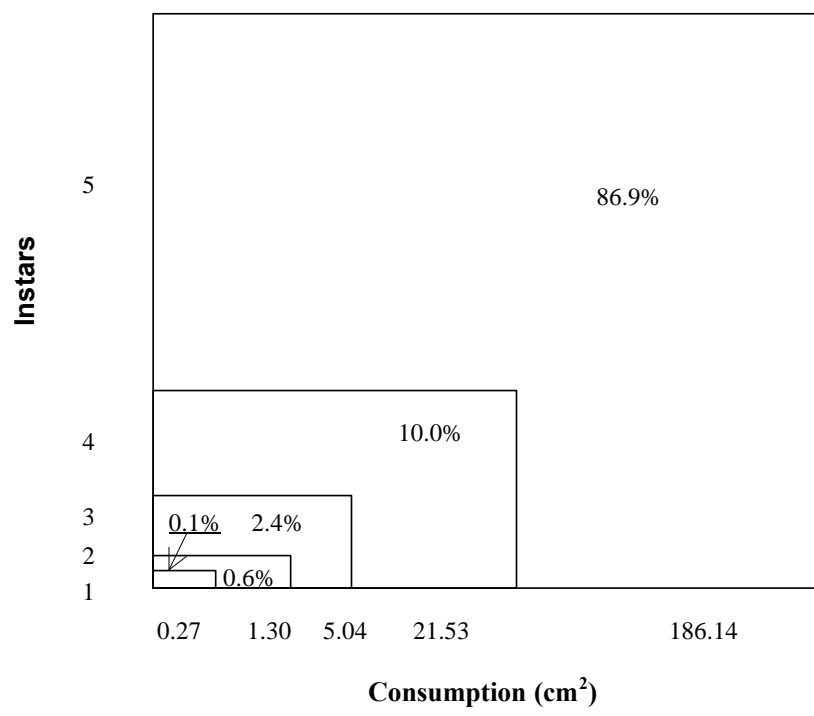

Figure 2 - Schematic representation of soybean leaf area consumed by Urbanus proteus proteus caterpillars during different instars, with their respective consumption percentages per instar.

\section{ACKNOWLEDGEMENTS}

To Dr. José Maria Milanez for critically reading the manuscript and for suggestions, and to Dr. Olaf H.H. Mielke for identifying the species.

\section{REFERENCES}

CARVALHO, A.G.; SILVA, M.R. Comparative biology of Urbanus proteus (Lepidoptera: Hesperiidae) in Centrosema pubescens, Clitoria fairchildiana, Glycine max and Phaseolus vulgaris (Leguminosae). In: INTERNATIONAL CONGRESS OF ENTOMOLOGY, 21., Foz do Iguaçu, 2000. Abstract. Foz do Iguaçu, 2000. p.234

COSTA LIMA, A.M. Insetos do Brasil: Lepidópteros. Rio de Janeiro: Escola Nacional de Agronomia, 1945. 379p. (Série Didática, 7)

GALLO, D.; NAKANO, O.; SILVEIRA NETO, S.; CARVALHO, R.P.L.; BATISTA G.C.; BERTI FILHO, E.; PARRA, J.R.P.; ZUCCHI, R.A.; ALVES, S.B.; VENDRAMIM, J.D. Manual de entomologia agrícola. 2.ed. São Paulo: Ceres, 1988. 649p.

GREENE, G.L. Economic damage levels of bean leaf roller populations on snap beans. Journal of Economic Entomology, v.64, p.673-674, 1971

HADDAD, M.L.; MORAES, R.C.B.; PARRA, J.R.P. Sistema computadorizado para modelos bioestatísticos aplicados à entomologia. In: CONGRESSO BRASILEIRO DE ENTOMOLOGIA, 15., Caxambu, 1995. Resumos Caxambu: SEB, 1995. p.224.

HIGLEY, L.G. New understanding of soybean, defolation and their implication for pest management. In: COPPING, L.G.; GREEN, M.B.; REES, R.T. (Ed.) Pest management in soybean. Londres: SCI Elsevier Applied Science, 1992. p.56-65.

KOGAN, M.; TURNIPSEED, S.G. Soybean growth and assessment of damage by arthropods. In: KOGAN, M.; HERZOG, D.C. (Ed.) Sampling methods in soybean entomology. New York: Springer Verlag, 1980. cap.1, p.3-26.

PARRA, J.R.P.; HADDAD, M.L. Determinação do número de ínstares de insetos. Piracicaba: FEALQ, 1989. 49p.

PEREYRA, P.C. Consumo foliar de soja por la "oruga medidora" Rachiplusia nu (Lepidoptera: Noctuidae). Revista de la Sociedad Entomológica Argentina, v.57, p.41-44, 1998.

TURNIPSEED, S.G. Response of soybeans to foliage losses in South Carolina Journal of Economic Entomology, v.65, p.224-229, 1972.

VAN DAM, W.; WILDE, G. Biology of the bean leafroller Urbanus proteus (Lepidoptera: Hesperiidae). Journal of the Kansas Entomological Society, v.50, p.157-160, 1977.

WALDBAUER, G.P. The consumption and utilization of food by insects. Advances in Insect Physiology, v.57, p.229-282, 1968.

Received June 20, 2001 